\title{
Ximena Alomía
}

Peruvian University of Applied Sciences (Peru)

Francisco Arbaiza

Peruvian University of Applied Sciences (Peru)

Advertising has been present in people's lives through strategies for the sale of products, satisfying their needs, and interacting with them. The advertising of beauty and feminine care products has been one of the most constant through the traditional formula of using stereotypical models of women highlighting their beauty and perfection. However, the evolution of advertising and the empowerment of women is generating new responses in consumers. Precisely, the purpose of this exploratory study is to identify the perception of Peruvian women on how advertising represents the 'real woman' in Peru in the field of beauty and personal care products. This study concludes that Peruvian women recognize that there is still a limited presence of 'real women' in advertising despite the widespread social demand for a change in the advertising discourse.

Keywords: stereotypes, perception, advertising, commercial broadcasting.

A dvertising has had a representative role within society for years by using advertisements that present the reality in matters of social order, displaying consumer lifestyles, and promoting products and services that they prefer (Vidal, Nuño, and Medrano, 2011).

The image of the perfect woman in advertising has been the focus of several ad campaigns, as it is used to, presented alongside the product or service thus having different personifications (Vidal, Nuño, and Medrano, 2011). These personifications made by the brands were based on the canons of beauty and idealization, regarding their bodies and attitude, and accepted by society 
(Cabrera, 2010). This characterization has contributed to the intensification of stereotypes. The womans body, having been exposed for years to the gaze and social judgment, has served as an object in advertising, producing in many individuals, anxiety and insecurity about their physique (Borau and Bonnefon, 2016). The stereotypes associated with what is mentioned before, have managed to pigeonhole them into roles attributed to beauty and perfection, which has generated a mistaken idea among consumers about how the behavior of women should be.

Treviños and Díaz-Soloaga (2018) suggest that distortion of reality has been generated because the stereotypical model of women in advertising is different from real women who are ultimately consumers of beauty and female care products. From this, the media has ended up fixing and naturalizing these stereotypes, making beauty what the media say it is (Borau and Bonnefon, 2016). To address this normalization, some beauty and feminine care brands have chosen to feature 'real' women in advertising. When 'real' women are mentioned, reference is made to the diversity of women that exist in our society, emphasizing that there is no specific model, but rather a variety of beauties and female bodies within society (Bolt, 2014). Dove, a pioneer brand in this transformation, for some years has tried to send positive messages to its consumers, on matters of acceptance, self-worth, and real beauty, configuring itself as a conscious brand committed to building relationships and conversations with its consumers (Persis, 2012).

In the same way, other female consumer brands have followed this example, thus obtaining different reactions and comments from the public (Velandia and Rodríguez, 2011; Vega, Barreda, and Merchán, 2019). However, past studies have obtained information on women from different cultures, which could vary the answer depending on the society in which the research is carried out. Advertising of beauty products has focused on presenting an idea of a woman; one that has been displayed in different countries and even using the same model of perfection. In the last decade, this situation has changed, and the transformation in the advertising discourse that we are currently seeing is an important matter of interest to different investigations.

In the Peruvian context, some studies have addressed these issues, but they have focused on the search for representation and conformation of a specific identity (Duche et al., 2019). Other authors have focused on the analysis of the generation and reproduction of discourses and imaginaries about what 'a man is' or what 'a woman should be', imparted and learned from the different media (Mendoza, 2012). Research has come a little closer to women's perceptions regarding the use of certain stereotypes in Peruvian advertising.

Considering the situation of Peru and its ethnic diversity, the following research aims to identify specifically the perception of the Lima consumer about the advertising of beauty and feminine care products discourse that presents the concept of a 'real woman' within the narrative. To meet this objective, the following research question was defined:

QI: What is the perception of Peruvian women about how advertising represents the 'real woman' in Peru, in the specific field of beauty and personal care products? 
In addressing the research question, this study explores what a segment of Peruvian women understands and projects about the presence of the 'real woman' in commercial messages, from their own experience and that of their peers. Likewise, focusing on the perceptions of this group of women can provide information about the consumer in aspects other than the commercial dimension.

This work has an exploratory scope on the perception that Peruvian women have about the advertising discourse in the industry; Learn about their beliefs and interpretations on the matter, adding new information to the body of knowledge for future theoretical elaborations and development of study instruments. To achieve this goal, qualitative methodology is proper since its objective is not to generalize knowledge to a population, but to understand the experiences of specific groups of individuals, or else about a particular phenomenon, in their environment.

\section{STEREOTYPES IN THE ADVERTISING OF BEAUTY AND FEMININE CARE PRODUCTS}

Martín (2012) points out that advertising normally portrays consumers through models, which present roles associated with them. These roles are manifested through stereotypes; by those means, advertising can reduce, naturalize, and fix differences. A stereotype is a concept that reflects inferior judgment and gives rise to a simple structure, implying a high probability that stereotypes are predominantly evaluative (Perkins, 1997; Zotos and Tsichla, 2014). Although stereotypes do not necessarily bear negative connotations, they may lead to oversimplified conceptions and expectations that devaluate and restrict potential opportunities of subjects of a social category (Zotos and Tsichla, 2014).

The gender stereotype, defined as beliefs that certain attributes differentiate women and men, has been used frequently as a resource in the presentation of advertising campaigns, these are constituted by those representations related to the image of men or women, which are the product of a biased perception of their behavior and attitudes (Treviños and Díaz-Soloaga, 2018).

As Cabrera (2010) recalls, in advertising, it is possible to perceive how women are portrayed mainly in three categories: Firstly, concerning the family as a housewife, wife, and mother; secondly, an attractive woman; and thirdly, a professional woman. This representation of beauty implies canons of physical perfection, presenting images of women that can be considered ideal and perfect models, thus feeding the dissatisfaction and insecurities of consumers, transferring that insecurity to different areas of their lives (Cabrera, 2010). This trend is especially reflected in the sale of feminine products since women tend to be judged mainly by their attractiveness (Chitty and D'Alessandro, 2011).

The advertising of the feminine beauty and care category implies women under this demanding stereotype, presenting them with a young, slim, white aesthetic profile among other characteristics associated with the 'perfect woman' (Muñoz and Martínez, 2019). The idealization of these patterns can 
become an aspiration in women, considering that personal grooming will enable better social relationships, and even generate happiness and satisfaction in them when they achieve it (Guzmán, 2016). It has been shown that not succeeding in this matter tends to generate feelings of dissatisfaction and insecurity in consumers when they observe the images presented (Borau and Bonnefon, 2016).

For some experts, the iconic campaign 'Real Beauty' of Dove meant the turning point in the narrative of the brands of the feminine beauty and care category (Feng, Chen, and He, 2019), and was considered the pioneer in breaking with use of hegemonic stereotypes and redefining the concept of "beauty", empowering women about their bodies (Couture and Harrison, 2019; Sternadori and Abitbol, 2019; Feng, Chen, and He, 2019). According to other experts like Persis (2012), the concept of 'real beauty' communicates meanings of liberation and oppression, considering that the discourse connects ideological and physical nonconformity of the dominant ideology with a woman's inability to fulfill her gender role or experience happiness (Couture and Harrison, 2019).

However, there was no lack of contrasting voices that also criticized the success of the campaign claiming that its objective was solely commercial and not social (Feng, Chen, and He, 2019). This perspective considers that this is one more self-serving strategy for accomplishing audience identification highlighting social issues as a means of generating sales (Johnston, Taylor, and Whitehead, 2014).

For Feng, Chen, and He (2019), Dove appropriates feminist values and empowers women, encouraging the consumption of the brand through the 'real beauty' campaign, achieving two objectives: it generates feelings in consumers identification and security by sending positive messages about beauty, and at the same time produces higher sales in the market. Dove is considered an innovative brand, which presents different models of women and which shows that all women are beautiful (Feng, Chen, and He, 2019).

Besides Dove, further studies have remarked the success of body diversity exposure (Rodgers et al., 2019; Convertino et al., 2019). In the specific case of Peru, society is in the difficult search for representation and conformation of an identity while it is inserted in globalized networks of production and symbolic circulation that establish trends, editorial lines, fashion and advertising. In Peru, social images have maintained a resentful racial fragmentation (Duche et al., 2019). According to Mendoza (2012), in Peruvian women, the representation in traditional advertising is often variable and incomplete. Through these stereotypes — which can be extreme and even laughable-, many Peruvian women try to build or reinforce their identity: they must be admired for being beautiful, to marry and to become mothers (Mendoza, 2012). Despite the fact that a change on this mindset is already taking place in large segments of the population, there is still many women - and men- who still believe in these canons and build their world with what their training allows them to encode and understand. It can then be anticipated that advertising has been projecting a disrupted image for decades. 


\section{METHODOLOGY AND PROCEDURES}

Given the exploratory nature of this research article that seeks to understand the perception of young women about how advertising represents the 'real woman' in Peru, in the specific field of beauty and personal care products, the most appropriate methodological approach was the qualitative one. This methodology allows us to explore the experiences and perceptions, as manifested by individuals (Daymon and Holloway, 2010; Patton, 2002).

\section{STUdy Design}

The analytical approach of this study was carried out following a phenomenological design. Through this qualitative approach, the researchers aimed to understand the experience of human life, based on the information that the individual offers in the first person, and whose meanings are shared among other people, from their own subjective experiences (Graneheim and Lundman, 2004).

\section{SAMPLE}

Gentles, Charles, Ploeg, and McKibbon, (2015) argue that the goal of sampling in qualitative research is to acquire useful information to understand the complexity, depth, and context surrounding a phenomenon, rather than the generalization sought by quantitative studies. To obtain this useful information, Palinkas et al. (2015) argue that qualitative sampling strategies should be oriented to select people, or data sources, considered 'information rich'.

The selection of participants was carried out through an intentional sampling. Intentional sampling is the selection of information-rich cases for indepth study, where those who learn about the central topic of the research are examined (Patton, 2002; Palinkas et al., 2015). The fundamental interest here is not to measure, but the understanding of the complexity of the phenomenon. For the total sample of the study, sixteen women who fulfilled all the inclusion criteria to become a source of relevant information were considered. Eight pairs of friends in total. intentional sampling. In order to identify participants who could be sources of relevant information, a series of inclusion criteria were defined (Daymon and Holloway, 2010). Only women who met all of the criteria listed below could be part of the study.

The participants are consumers of beauty and feminine care products. In order to identify participants who could be sources of relevant information, a series of inclusion criteria were defined (Daymon and Holloway, 2010). Female women who met all of these criteria could be included in the research, based on the lifestyle study by Arellano Marketing (2017). The inclusion criteria were:

- Demographic variables: Women between the ages of 25 and 35 from SES A and $\mathrm{B}$, resident in Lima.

- Psychographic variables: Women who work, some carry out studies to complement their professional line and like to constantly learn. They are 
modern, they are attentive to trends, they like to make different purchases, especially investing in products that take care of their appearance and are of quality. Most of them are financially independent and have a home. Enjoy sharing moments with their friends, outings and conversations with them. Communicative and friendly.

- Social and cultural variables: Lima women make different purchases through various platforms; in the case of beauty and feminine care products, it is preferred by consumers. Brands carry out campaigns aimed at this audience, being close to women and providing information and quality to them. Women look for effectiveness in the products they use, in the same way, they look for products that reaffirm their security and confidence in them.

The initial selection was made by identifying participants who met the inclusion criteria. After selecting the first two participants, a snowball or referral sampling strategy was followed, whereby those interviewed referred new participants as sources for study. Authors argue that the snowball strategy is one of the practices of purposive sampling (Daymon and Holloway, 2010; Patton, 2002; Gentles et al., 2015).

In this mode of approach, it is possible to work with relatively small numbers of observation units, as long as each unit is carefully and intentionally selected for its possibilities of offering detailed and in-depth information on the subject of interest of the research. These types of decisions, which in a probability sampling design would be considered as sources of bias, in a qualitative inquiry like this are a way to guarantee the rigor of the approximation.

The generally accepted criterion in qualitative research for determining when a sufficient sample size has been reached is data saturation (Gentles et al., 2015; Morse, 1991). Fusch and Ness (2015) note that saturation is identified when the researcher reaches the point of no new data in their sources or, in the words of Palinkas et al. (2015), when no new substantive information is no longer acquired, or according to Saunders et al. (2018) when additional data collection or analysis is no longer necessary.

\section{Data Collection and Procedure}

Data collection was carried out through in-depth interviews. This instrument is widely used in qualitative studies, mainly in those that seek to understand subjective experiences, feelings or beliefs of people (Crouch and McKenzie, 2006). The in-depth interview is generally used in phenomenological design studies, due to the interest in knowing the phenomenon as it is experienced by other subjects.

An inquiry guide was developed for them. To address the research question, the guide framed three topics:

- Consumption of feminine care and beauty products,

- Advertising of feminine care and beauty products, and

- Perception of advertising spots for feminine care and beauty products. 
Table 1 shows the themes and questions used to guide the interviews. Firstly, closed questions were asked, in relation to the consumer products they use, what they are and why they use them, thus obtaining their consumer preferences; second, semi-structured questions, which consisted of more research-directed questions, such as the advertising they consume, women and their representation. Finally, in the third part, structured questions were asked. At this point the questions were specific about the ad, the comparison and their opinion regarding what was observed. These questions were asked to all participants, always in the same order, to keep the information collected within the framework of the research (Fusch and Ness, 2015).

The interviews were conducted by the same researcher, and individually with each participant. The researcher had no previous interaction with the participants and contact to coordinate the interviews was made by e-mail. The interviews lasted between 50 and 60 minutes, and all were digitally recorded and transcribed for later analysis of the reactions and opinions of the interviewees, through the qualitative data software NVivo 12.

\section{Table 1. Topic and Questions. Guide for in depth interviews}

\begin{tabular}{|c|c|c|}
\hline Topic & Kind of & Questions \\
\hline $\begin{array}{l}\text { Consumption of } \\
\text { feminine care and } \\
\text { beauty products }\end{array}$ & $\begin{array}{l}\text { Closed } \\
\text { questions }\end{array}$ & $\begin{array}{l}\text { 1. What type of feminine care and beauty products do you } \\
\text { consume? } \\
\text { Consider using them? } \\
\text { 3. What brands of beauty and feminine care products do you } \\
\text { use? } \\
\text { 4. What factor could determine why you use a different brand } \\
\text { than the one you use? }\end{array}$ \\
\hline $\begin{array}{l}\text { Advertising of } \\
\text { feminine care and } \\
\text { beauty products }\end{array}$ & $\begin{array}{l}\text { Semi-Structured } \\
\text { Questions }\end{array}$ & 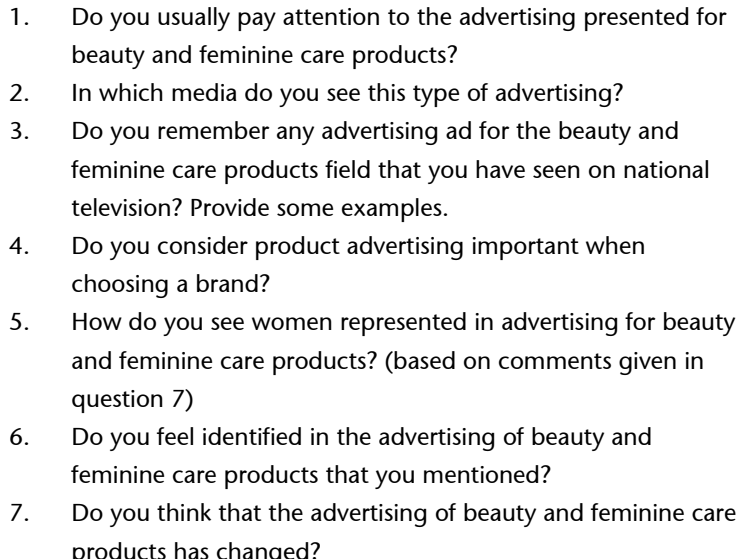 \\
\hline
\end{tabular}




\begin{tabular}{|c|c|c|c|}
\hline 176 & Topic & Kind of & Questions \\
\hline 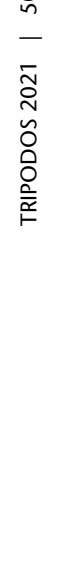 & $\begin{array}{l}\text { Perception } \\
\text { of advertising } \\
\text { ads for } \\
\text { feminine care } \\
\text { and beauty } \\
\text { products }\end{array}$ & $\begin{array}{l}\text { Structured } \\
\text { Questions }\end{array}$ & $\begin{array}{l}\text { 1. After observing the ads, is there one that you liked the most or } \\
\text { 2. What was the advertisement that most impressed you? } \\
\text { 3. Regarding the advertisements presented about beauty and } \\
\text { feminine care products, which brands would you prefer to use } \\
\text { based on the advertising message they have sent? } \\
\text { 5. Do you think that the message presented by the brands would } \\
\text { change your decision making to opt for a product? } \\
\text { 7. In presented? } \\
\text { 8. Would you choose a brand knowing that it has a positive } \\
\text { message and inspires women? } \\
\text { care products could show? }\end{array}$ \\
\hline
\end{tabular}

Source: Own creation.

Regarding the ethical aspects of the research procedures, anonymity and confidentiality of the participants' information were maintained. Participants agreed to participate on a voluntary basis, and a briefing was conducted before they signed the informed consent form. In the briefing, it was explained to them that they would be participating in a study on advertising.

At the end of the interview, a debriefing was conducted with each participant, offering more detail on the objectives of the study.

The choice of advertising ads was divided into two segments: four brands that feature the 'real woman' and four brands that showcase the 'perfect woman' from the beauty and skin care category that were broadcast in Peru in a range of less than 3 years. These ads point to a similar target audience, this contributed to determine the participants based on prior knowledge of these brands. Table 2 describes the selected advertisement ads.

\section{Table 2. Advertisements that represent the 'perfect woman' and the 'real} woman'

\begin{tabular}{l|l|l} 
Brand and Ad & Description & URL \\
\hline $\begin{array}{l}\text { Ésika (perfect woman) } \\
\begin{array}{l}\text { Colorfix, All-Proof Long Lasting } \\
\text { with New Formula (2019) }\end{array}\end{array}$ & $\begin{array}{l}\text { During the commercial, Greeicy } \\
\text {-a worldwide known singer-, } \\
\text { presents the benefits of this } \\
\text { products. }\end{array}$ & <https://youtu.be/JuUyvaCpF10> \\
\hline $\begin{array}{l}\text { Maybelline (perfect woman) } \\
\text { New tattoo brow peel off (2019) }\end{array}$ & $\begin{array}{l}\text { Maybelline presents a new } \\
\text { product. The ad is featured by a } \\
\text { model. }\end{array}$ & $<$ <https://youtu.be/X9n8SFZCCv0> \\
\hline
\end{tabular}




\begin{tabular}{|c|c|c|}
\hline Brand and Ad & Description & URL \\
\hline $\begin{array}{l}\text { Nivea (perfect woman) } \\
\text { Show off your armpits without } \\
\text { worries with (2016) }\end{array}$ & $\begin{array}{l}\text { Nivea presents the deodorant } \\
\text { that lightens the underarm } \\
\text { tone. In the ad, the commercial } \\
\text { stars a stereotypical woman } \\
\text { being attractive while using the } \\
\text { product. }\end{array}$ & $<$ https://youtu.be/GPb_Ft75wfE \\
\hline $\begin{array}{l}\text { Pantene (perfect woman) } \\
\text { New Shampoo Minute Miracle } \\
(2019)\end{array}$ & $\begin{array}{l}\text { Pantene shows a confident and } \\
\text { assured woman. The ad ends } \\
\text { showing the woman happy, } \\
\text { radiant and with perfect lush hair. }\end{array}$ & <https://youtu.be/GE3cVUA_hE0> \\
\hline $\begin{array}{l}\text { Avon (real woman) } \\
\text { La belleza es libre (2019) }\end{array}$ & $\begin{array}{l}\text { Avon features women of different } \\
\text { ages, ethnicities, cultures, builds, } \\
\text { and heights. The ad mentions the } \\
\text { benefits, but also reveals how the } \\
\text { brand is committed to the daily } \\
\text { struggle of women. }\end{array}$ & <https://youtu.be/nwwINZQDeV4> \\
\hline $\begin{array}{l}\text { Dove (real woman) } \\
\text { \#MuéstranosMujerPeruana } \\
\text { (2019) }\end{array}$ & $\begin{array}{l}\text { Dove displays several images } \\
\text { of Peruvian women located in } \\
\text { different parts of the country. The } \\
\text { combination of colors, settings } \\
\text { and faces stand out throughout } \\
\text { the commercial. }\end{array}$ & <https://youtu.be/3uzNLXpRorc> \\
\hline $\begin{array}{l}\text { Natura (real woman) } \\
\text { \#PorUnMundoMasBonito (2019) }\end{array}$ & $\begin{array}{l}\text { The ad raises the question: What } \\
\text { can a beauty brand do for your } \\
\text { body? This is answered: 'You } \\
\text { have to help change the meaning } \\
\text { of the perfect body'. }\end{array}$ & <https://youtu.be/DzZ7tKppSRQ> \\
\hline $\begin{array}{l}\text { Sedal (real woman) } \\
\text { Re-think Pink, together (2019) }\end{array}$ & $\begin{array}{l}\text { The ad projects these women } \\
\text { changing the meaning of } \\
\text { the color pink, no longer as a } \\
\text { synonym for weakness, but for } \\
\text { strength. }\end{array}$ & <https://youtu.be/HckQu-TQ4tU> \\
\hline
\end{tabular}

Source: Own creation.

\section{RESULTS}

After carrying out the data collection process obtained in the interviews, five categories emerged from the analysis. The objective was to find out the perception of women living in Lima regarding the change in the advertising discourse from 'perfect woman' to 'real woman' in the advertising of beauty and feminine care products. 

woman and industry advertising

This category expresses how consumers observe women in advertising. After the participants would comment on what they are based on to choose a cosmetic or feminine care product, they were asked questions focused on the representation of women in the advertisements of this area. The interviewees expressed the prototype that is still used in advertisements, describing them with similar characteristics.

One of the participants commented:

They are always girls with long hair, or with super neat, soft skin, with slim bodies. So far, I don't see there is a change in that regard. She is still the same perfect girl model (...).

Others expressed their opinion regarding the attitude shown by women in the different advertisements:

In the advertising in which I see they continue to treat women or put them in a rather feminine role, special care (...).

Women still link the advertising of beauty and feminine care products as an area that still works with stereotypes focused on the physical and femininity, which manifest roles associated with women, roles that have been associated with them due to their gender during years. When discussing the representation of women in advertising, questions were asked regarding the identification they feel as consumers concerning the advertising they have previously observed.

The responses were diverse; among the responses they commented that they do not feel identified since the product shows results and the consumers are not able to replicate them, for example:

Until now, I have not seen advertising with which I have seen myself identified. It never got to have what the product wants to offer me.

On the other hand, wanting to obtain effects that are seen in advertising manifest the desired desire they have when using these products:

I feel like the brand shows you the benefit it offers you, one is what it wants to project ... identified no I am sorry, but I would like it to stay like in the commercial.

The category notices how consumers still relate the beauty category with already established models presented, and although they do not generate identification in them, produce a desire to achieve the benefits offered by the different brands through the advertisements they make. 
Category 2. The need to present the 'real woman' in current advertising is recognized as obvious

This category describes the appearance of the 'real woman', showing her inclusion thanks to the evolution that has emerged in current advertising. Responses were obtained when consulting if they consider that there has been a change in advertising, obtaining statements about whether there has been an evolution.

The participants consider that there has been a change; one of them said:

I think so, now women are represented differently. She is no longer the typical blonde, blue-eyed model that appears on television, if she is not a more real woman, and I think the time in publicity has improved a lot. It is much more motivating to buy a product that is used by a real woman than to be tried by a model who has a different life.

Likewise, they relate the evolution of advertising with inclusion when presenting real women, creating in them a feeling of belonging:

As time progresses, the issue of cosmetic products, feminine products, becomes more human. More than anything an issue of inclusion, I think that is very present in most brands and we like it because we feel part of... it is something more real, all kinds of women.

On the other hand, this category also exposes the intentions of consumers to witness a more significant evolution by beauty and feminine care brands. One of the interviewees commented:

I think it could be more significant, even not having a stereotype of a girl or a woman to advertise a makeup. If not to be more universal.

They also expressed that they applaud the brands that are venturing, but that they would like this action to be replicated in different brands located in the category:

Yes there is a big difference, but I would like this change to be a little faster and that all brands can imitate those who are daring. Peruvian women are so diverse that they do not fit into that prototype that many brands want because that prototype of women has always been imposed.

The inclusion of the 'real woman' is manifesting itself in advertising. The diverse woman, the real woman, has more and more space in advertisements. Consumers recognize it and express a desire to observe it even more in the advertising of different brands, not just a few. 
This category presents the messages transmitted by a brand, influencing the decision-making of consumers when purchasing a product. The message that brands send, whether positive or negative, influences the consumer's purchase decision; however, it is not a determining factor for changing brands or purchasing a product.

When making the purchase of a product or acquiring a specific service, consumers are informed about the brand or inquire about it through the internet, social networks, or known people. One of them expressed her relationship with advertising when buying a product and the intention that it will generate in it:

I am not influenced much by advertising, but it would catch my attention and if I could try it. But it would not be as if well I see the message and would buy one. I would continue as before looking for information and if I see that it will suit me, I will buy it.

In the same way, interest is generated in them when they perceive a positive message:

I think that if I would buy and support the brands that are focusing more on the messages that take women out of the label, they are on (...).

The influence of messages is important to consider when acquiring or testing a brand, but the quality and benefits offered by the product are fundamental when deciding a product, especially in the area of beauty and feminine care as it is specialized products. Consumers make a purchase having carried out a preliminary investigation of the brand.

The messages generate curiosity in the consumer, creating an intention to search for the product and considering it in a possible purchase, as long as it involves quality and meets the desired needs. However, if a brand presents negative messages it could lead to rejection by women. For example:

If I see an advertisement that stereotypes women a lot or says a message that I do not agree with, I completely stopped buying the brand. When you buy the product of a company you are a little supporting what that company does, what that company says. If the publicity goes with my values, with my mentality, with more reason I am going to buy it.

When choosing a brand, you choose the message it sends as a brand.

Companies express themselves through the advertising messages which they send to their consumers, the image they project is what they prove to be. This is the reason why consumers are guided by the message to opt for a product or not; in this case, to decline a brand by presenting a negative image. 
Category 4. The representation of the 'real woman' in the advertising message stands out for its low presence

This category explores the 'real woman' in the Peruvian environment, showing that remembrance is null. Ads showing 'real woman' were presented. These were made and/or issued in Peru during 2018 and 2019; However, the interviewees expressed surprise when observing these commercials. They commented that they had not previously observed them and even expressed their pleasure to know that positive messages are being evidenced through advertising.

The most prominent brand was Dove, a brand recognized for presenting campaigns such as 'real beauty'. In the study, the brand had a higher preference due to the message directed at Peruvian women, an ad that presented women from different areas of Peru and revalued Peruvian beauty. After presenting the ads, one of the interviewees expressed:

I loved that advertising, I feel that it is the one that has impacted me the most because not only shows the average person, but does not show people from the interior of the country and I feel that not many Brands risk playing with that concept. It was something I hadn't seen before.

They highlighted the brand when considering that it focused on advertising in Peru and for Peruvians, which they had not witnessed before:

It is more personalized at a national dimension ... advertising uses a stereotype of a person, whether man or woman, who it does not apply to all countries. It seems ideal to me that the advertising is based locally, nationally. They show faces that you can see on the street so you can identify yourself.

In general, brands carry out a campaign, in this case, ads which are broadcast internationally, providing the consumer with a stereotype which they try to replicate in different countries. Observing an international brand like Dove, focusing on advertising in the country and speaking to Peruvian women, showing women from the country, generated satisfaction in the interviewees, but moreover, astonishment.

Consumers consider that the image of Peruvian women is not usually exposed in advertisements, this is why witnessing a brand oriented in Peru generates a positive perception of the brand, especially with Dove being a recognized brand at the international level.

\section{Category 5. Women would opt for brands that meet the needs of real women in real cases}

This category describes the desire of women to use products that present real models, demonstrating the effectiveness of the products in women similar to them. Beyond the representation and identification with women on an emotional level, they express that the fact of using products that have been used by normal women produces in them security of obtaining desired effects, compared to products where they advertise a 'perfect woman'. The desire of 
women is revealed, considering the recommendation as a determining factor for choosing a product. Women were more persuaded towards recognized brands, which present close models, generating empathy with consumers through the presentation of real cases and demonstration of product use.

An example of this is expressed by one of the interviewees:

See how the product works objectively, see what happens, how it works. In real cases it is something that I would love to see in advertising.

Observing the functionality of the product causes the consumer to have greater confidence in it. Likewise, the importance of the 'real woman' in advertising is emphasized, rather than the presentation of the 'perfect woman':

Encourage the integration of the Peruvian woman, the classic Peruvian woman and not that ideal woman who treats us to impose on society. Inform more about the products (...).

In the same way, women accept the new model that is presented of women when they consider that they are real models, models that they observe on a day-to-day basis and with whom they can feel identified:

In the end, it is real women who buy from you. The product is not the model (...) if not the woman who has a need to cover, that is the final consumer of the product.

\section{CONCLUSIONS}

The incidence of the 'perfect woman' is still present in advertising in Peruvian advertising, it is considered as a reference within the category of beauty and feminine care products. The comments obtained by the women allowed them to recall their perceptions, considering that the 'perfect woman' is an idealization of what women should be, which generates a lack of identification with the brands that present it. That is why the preference of the 'real woman' is natural for them, since they manage to feel identified with them and generate a positive perception of the brand.

Finally, there is still a lack of visualization of the 'real woman' in advertising, considering the consumers, who in the Peruvian sphere still do not observe this woman, even when presenting ads broadcast in Peru, few remembered having seen those ads. In addition, they pointed out that few international brands have made advertising focused on Peruvian women, considering that Dove is one of the few brands that has shown the diversity of women in the country.

Peruvian advertising has insisted on perpetuating idealized representations. However, it has been possible to appreciate how the commitment to advertising messages from brands that promote diversity and seek to break down stereotypes in their campaigns is welcomed by consumers. Certainly, the participants of this study consider that this new narrative in advertising calls for the acceptance and positive valuation of Peruvian women. It can be anticipated that the presence of 
this strategy on brands narrative, despite its commercial objectives, contributes, in the long term, to building a new panorama characterized by diversity.

The following study had limitations. The little literature on Lima consumers does not allow comparisons with prior studies conducted in Peru. In the same way, in relation to the findings obtained on the customers' preference based on the previous information they have about a brand that they wish to use, is minor. The approach of the previous studies is based on perceptions obtained from women, who comment on how they observe advertising, but not that it determines that they finally opt for a product. The participants were part of a similar socioeconomic level, with an age range of 25 to 35 years. The study could have a variation if it was focused on a smaller range of years. In the case of women from 25 to 30 years old, the participants look for references of beauty products, but advertising still influences them a lot. In contrast, women aged 30 to 35 rely more on product information and quality than on advertising.

Future research may focus on how women perceive advertising and make a purchase decision based on it. The purchase decision is essential since it is ultimately what advertising does to achieve it. In the findings, information was obtained on consumers residing in Lima and how they perceive advertising; however, it is possible to obtain more information than what is already given.

Ximena Alomía (U201413187@upc.edu. pe). Researcher graduated from the Peruvian University of Applied Sciences (UPC), particularly interested in research associated

Francisco Arbaiza (francisco.arbaiza@upc. edu.pe). University professor and researcher oriented to the study of new trends in contemporary marketing at the Peruvian University of Applied Sciences (UPC). PhD in Public Communication at the University of Navarra (Spain) and BA at the University of Piura. Particularly interested in the influence with advertising and its relationship with discourse. Skilled in conducting qualitative research; leading workshops; researching media, inclusion, difference, and diversity.

of the consumer experience in commercial communication. His current research projects include: Experiential Marketing and the profile of the new consumer in contemporary marketing; the implications of advertising discourse in branding and in the social context; and brands-consumer interaction in new digital scenarios.

\section{References}

Arellano Marketing (2017). "Estilos <https://www.arellano.pe/los-seis-estilos-dede vida". Arellano Marketing. Available at: vida/>. Accessed 06 June 2019. 
Bolt, David (2014). “An Advertising Aesthetic: Real Beauty and Visual Impairment". British Journal of Visual Impairment, 32(1), pp. 25-32. <https://doi.org/10.1177\% 2F0264619613512619>.

Borau, Sylvie and Bonnefon, Jean-Francois (2016). "The Advertising Performance of Non-ideal Female Models As a Function of Viewers' Body Mass Index: A Moderated Mediation Analysis of Two Competing Affective Pathways". International Journal of Advertising, 36(3), pp. 457-476. <https://doi.org/10.1080/ 02650487.2015.1135773>.

Cabrera, Yolanda (2010). "El cuerpo femenino en la publicidad. Modelos publicitarios entre la belleza real, la esbeltez o la anorexia". Icono, 14, 8(3), pp. 223-243. <https://doi. org/10.7195/ri14.v8i3.236>.

Chitty, Bill and D'Alessandro, Steven (2011). "Real or Relevant Beauty? Body Shape and Endorser Effects on Brand Attitude and Body Image". Psychology and Marketing. Vol. 28(8), pp. 843-878. <https://doi.org/10.1002/ mar.20415>.

Convertino, Alexandra D.; Rodgers, Rachel F.; Franko, Debra L., and Jodoin, Adriana (2019). "An Evaluation of the Aerie Real Campaign: Potential for Promoting Positive Body Image?". Journal of Health Psychology, 24(6), pp. 726-737. <https://doi. org/10.1177/1359105316680022>.

Couture Bue, Amelia C. and Harrison, Kristen (2019). "Empowerment Sold Separately: Two Experiments Examine the Effects of Ostensibly Empowering Beauty Advertisements on Women's Empowerment and Self-objectification". Sex Roles, 81(9-10), pp. 627-642. <https://doi.org/10.1007/s11199019-01020-4>.

Crouch, Mira and McKenzie, Heather (2006). "The Logic of Small Samples in Interview-based Qualitative Research". Social Science Information, 45(4), pp. 483-499. <https:// doi.org/10.1177/0539018406069584>.

Daymon, Christine and Holloway, Immy (2010). Qualitative Research Methods in Pub- lic Relations and Marketing Communications. Abingdon: Routledge.

Duche, Aleixandre; Paredes, Fanny; Caballero, Carlos, and Arias, Dennis (2019). "¡Yo no soy esa mujer!: Un análisis antropológico de la imagen de la mujer andina desde la publicidad comercial televisiva". Revista Inclusiones, 6(1), pp. 233-253.

Feng, Yang; Chen, Huan, and He, Li (2019). "Consumer Responses to Femvertising: A Data-mining Case of Dove's 'Campaign for Real Beauty' on YouTube". Journal of Advertising, 48(3), pp. 292-301.<https://doi.or g/10.1080/00913367.2019.1602858>.

Fusch, Patricia I. and Ness, Lawrence R. (2015). "Are We There Yet? Data Saturation in Qualitative Research". The Qualitative Report, 20(9), pp. 1408-1416.

Gentles, Stephen J.; Charles, Cathy; Ploeg, Jenny, and McKibbon, K. Ann (2015). "Sampling in Qualitative Research: Insights from an Overview of the Methods Literature". The Qualitative Report, 20 (11), pp. 1772-1789.

Graneheim, Ulla and Lundman, Berit (2004). "Qualitative Content Analysis in Nursing Research: Concepts, Procedures and Measures to Achieve Trustworthiness". Nurse Education Today, 24(2), pp. 105-112. <https://doi. org/10.1016/j.nedt.2003.10.001>.

Guzmán, Nathaly (2016): "La ideología a través de la publicidad y las representaciones de género". Revista Realidad, 28, pp. 101-114.

Johnston, José; Taylor, Judith, and Whitehead, Krista (2014). "A Corporation in Feminist Clothing? Young Women Discuss the Dove 'Real Beauty' Campaign". Critical Sociology, 1, pp. 1-26. <http://dx.doi. org/10.1177/0896920513501355>.

Martín, Teresa (2012). "La mujer en la creatividad publicitaria del siglo XXI: De protagonista a profesional del mensaje publicitario". Revista 1, pp. 105-114. <http://dx.doi. org/10.33115/udg_bib/cp.v1i01.22142>.

Mendoza, Héctor (2012). "Entre el poder y el deber: La publicidad y su rol en la formación de estereotipos de género. Primeros apuntes". 
Correspondencias \& Análisis, (2), pp. 131-164. $<$ https://doi.org/10.24265/cian.2012.n2.07>.

Muñoz, Ana and Martínez, María del Mar (2019). "Representación iconográfica de las mujeres en la publicidad de perfumes". Signa: Revista de la Asociación Española de Semiótica, (28), pp. 1123-1148. <https://doi.org/10.5944/ signa.vol28.2019.25113 >.

Palinkas, Lawrence; Horwitz, Sarah; Green, Carla; Wisdom, Jennifer; Duan, Nalhua, and Hoagwood, Kimberly (2015). "Purposeful Sampling for Qualitative Data Collection and Analysis in Mixed Method Implementation Research". Administration and Policy in Mental Health and Mental Health Services Research, 42(5), pp. 533-544.

Patton, Michael (2002). Qualitative Research and Evaluation Methods (3rd ed.). Thousand Oaks, CA: Sage.

Perkins, Tessa (1997). "Rethinking Stereotypes". In: T. O' Sullivan and Y. Jewkes (eds.). The Media Studies Reader. Bristol: Arrowsmith.

Persis, Dara (2012). "Branding 'Real' Social Change in Dove's Campaign for Real Beauty". Feminist Media Studies, pp. 83-101. <https:// doi.org/10.1080/14680777.2011.647963>.

Rodgers, Rachel F.; Kruger, Lou; Lowy, Alice S.; Long, Stephanie, and Richard, Chloe (2019). "Getting Real about Body Image: A Qualitative Investigation of the Usefulness of the Aerie Real Campaign". Body Image, 30, pp. 127-134. <https://doi.org/10.1016/j.bodyim.2019.06.002>.

Saunders, Benjamin; Sim, Julius; Kingstone, Tom; Baker, Shula; Waterfield, Jackie; Bartlam, Bernadette; Burroughs, Heather, and Jinks, Clare (2018). "Saturation in Qualitative
Research: Exploring Its Conceptualization and Operationalization". Quality \& Quantity, 52(4), pp. 1893-1907.

Sternadori, Miglena and Abitbol, Alan (2019). "Support for Women's Rights and Feminist Self-identification As Antecedents of Attitude Toward Femvertising". Journal of Consumer Marketing, 36(6), pp. 740-750. <https:// doi.org/10.1108/JCM-05-2018-2661>.

Treviños, Doris and Díaz-Soloaga, Paloma (2018). "Estereotipos femeninos en anuncios gráficos de marcas de lujo de moda, perfumería y cosmética". Pensar La Publicidad, 12, pp. 145-164. <http://dx.doi.org/10.5209/ PEPU.60926>.

Vega, Silvia; Barreda, Daniel, and Merchán, Ana (2019). "Percepción de los comportamientos y patrones corporales asignados a la mujer en publicidad". Ámbitos. Revista Internacional de Comunicación, 44, pp. 162-180. $<$ https://doi.org/10.12795/Ambitos.2019. i44.10>.

Velandia, Andrea and Rodríguez, Rosa (2011). "Estereotipos femeninos y preferencia de consumo". Universitas Psychologica, 10, pp. 47-59.

Vidal, Pablo; Nuño, Teresa, and Medrano, María (2011). "Percepción del alumnado adolescente sobre los prototipos y estereotipos femeninos en la publicidad actual". Investigación y género, logros y retos: III Congreso Universitario Nacional Investigación y Género, pp. 2058-2082.

Zotos, Yorgos and Tsichla, Eirini (2014). "Female Stereotypes in Print Advertising: A Retrospective Analysis". Procedia - Social and Behavioral Sciences, 148, pp. 446-454. <https:// doi.org/10.1016/j.sbspro.2014.07.064>. 